\title{
Nutritive quality of romanian hemp varieties (Cannabis sativa $L$.) with special focus on oil and metal contents of seeds
}

\author{
Marcela Mihoc, Georgeta Pop*, Ersilia Alexa and Isidora Radulov
}

\begin{abstract}
Background: The study aims to determine the nutritional value of hemp seed expressed by the oil content and by the concentration of metals ( $\mathrm{Ca}, \mathrm{Mg}, \mathrm{K}, \mathrm{Fe}, \mathrm{Mn}, \mathrm{Zn}$ and $\mathrm{Cd}$ ), for five varieties of monoecious and dioecious hemp seeds approved in Romania, comparative with the concentration of these metals in the soil.

Results: The content of oil in hempseed registers a slight decrease in the production records of 2011, losses due to drought and low levels of precipitation during the growth period. The greatest loss is found in Diana monoecious variety (26.54-20.82\%) followed by Zenit varieties (27.37-22.97\%), Armanca (29.27-25.32\%), Silvana (28.89-25.04\%) and Denise (26.96-25.30\%). Siccative hemp oil has a yellowish green color and an iodine index of 140-156 g I2/100 g oil. Hemp seed are rich in mineral based Ca (144-955 mg/100 g seed), Mg (237-694 mg/100 g seed), K (463-2821 mg/ $100 \mathrm{~g}$ seed), Fe (1133-2400 mg. $\left.\mathrm{kg}^{-1}\right), \mathrm{Mn}\left(63-110 \mathrm{mg} \cdot \mathrm{kg}^{-1}\right)$ and $\mathrm{Zn}\left(42-94 \mathrm{mg} \cdot \mathrm{kg}^{-1}\right)$. For the soil the following macroelements concentrations were determined: Ca (2100-2520 mg.kg-1), Mg (320-376 mg.kg $\left.{ }^{-1}\right)$ and K (232-257 mg. $\left.\mathrm{kg}^{-1}\right) . \mathrm{Mn}\left(156-197 \mathrm{mg} \cdot \mathrm{kg}^{-1}\right)$ and Zn (54-67 mg. $\left.\mathrm{kg}^{-1}\right)$ remain within normal limits for Romania. The soils in the experience area contain large amounts of Fe (19000-20430 mg. $\left.\mathrm{kg}^{-1}\right)$. The presence of $\mathrm{K}$ in large quantities determines the accumulation of large quantities of Fe in the soil.

Conclusion: Hempseed belonging to the five Romanian varieties are rich source of nutrients $(\mathrm{Ca}, \mathrm{Mg}, \mathrm{K})$ and unsaturated oil easily digestible by the body, but the presence of $\mathrm{Cd}$ concentrations above the upper limit puts a question mark over the use of seeds in various food products. Hemp extracts easily certain metals from the soil. Significant amounts of Fe (1133-2400 mg. $\left.\mathrm{kg}^{-1}\right), \mathrm{Mn}\left(63-110 \mathrm{mg} \cdot \mathrm{kg}^{-1}\right), \mathrm{Zn}\left(42-94 \mathrm{mg} \cdot \mathrm{kg}^{-1}\right)$ and $\mathrm{Cd}\left(1.3-4.0 \mathrm{mg} \cdot \mathrm{kg}^{-1}\right)$ are found in hemp seeds. Hemp (Cannabis sativa $\mathrm{L}$.) is included among plants suitable for phytoremediation of soil contaminated with cadmium, zinc and iron.
\end{abstract}

Keywords: Hempseed, Oil content, Metal content

\section{Background}

In recent years, the desire to adopt a healthy diet, draws attention to hempseed and food products derived from hempseed (oil, flour, milk, bakery products, chocolate, beer, etc.). Hemp (Cannabis sativa $L$.) is a highly variable crop with varieties both for fiber and oil. Hemp seeds and hemp oil have a high nutritional value and both are used for human consumption and animal feeding [1-3]. The nutritional value of hemp seeds is based on the content of protein and oil. Hemp oil is particularly valuable

\footnotetext{
* Correspondence: getapop_tm@yahoo.com

Faculty of Agriculture, Banat's University of Agricultural Sciences and Veterinary Medicine, Calea Aradului 119, RO 300645, Timisoara, Romania
}

for the health because of its content in fatty acid, mostly being unsaturated acids, completed by high contents of phytosterols, but the properties of hemp oil are still little known in Romania [4-6]. The high price and reduced duration of keeping of the hemp oil translate in a low interest by the people for this alimentary supplement. Reduced supplies and the desire to get rich fast can bring a forged hemp oil on the market with an oil like the rapeseed oil. The authentication of the fatty acid in vegetable oils requires chromatography technique or FTIR spectroscopy $[7,8]$. The 3:1 perfect ratio of omega 6 and omega 3 brings results as treatment for various diseases such as cardiovascular problems, reduction of fibrinogen (in atherosclerosis), in the production of 
prostaglandins series 3 (PG3) [9,10]. The reduction of the cholesterol is a major benefit of $\beta$-sitosterols present in the unsaponifiable of the vegetable oils like rapeseed, soybean and the hemp oil [11]. This acid $\gamma$-linolenic

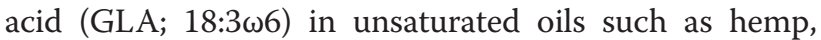
flax or evening primrose oil refreshes and moisturizes the skin even with anti aging effects [12]. Fat calories in your diet should not exceed 2500 calories/day. The daily 9-18 g/day LA (18:2 $\omega 6)$ and 6-7 g/day LNA (18:3 $\omega 3)$ provides the optimum fatty acid ration the body requires $[9,13]$.

Hemp is an excellent soil phytoremediation agent because it extracts heavy metals $[14,15]$. The use of hemp seeds in various derived foods and the consumption of supplements of hemp seeds bring attention to the potential negative effects of heavy metals possibly contained. Heavy metals are present naturally in soil in low concentrations. The presence of heavy metals in soil, as the natural background from pedogenetic processes or from human activities brings the current need to analyze their content in soil, water, air, crops and food. The capacity to absorb heavy metals depends on the geochemical characteristics of the soil and the nature of crops, some of them have a high potential to accumulate higher concentrations of heavy metals [15]. However, most crop plants can not survive on soils heavily contaminated with heavy metals [16].

Plants have different storage centers in vegetative and reproductive organs. Leaves can contain large quantities of metal, while the seeds have low metal amounts [17]. Thus, cereal grains accumulate low amounts of metals, while vegetables accumulate higher amounts especially in leaves $[18,19]$. Heavy metals are related to certain components of cell membranes, enzyme systems in the body or have the role of catalyst. Nutritional deficiency caused by lack of metals in food or the amount of metals exceeding a certain threshold, produces toxic effects. The implementation of procedures and control mechanism imposed by national and international regulations reduce considerably the maximum levels of toxic metals in food.

Hemp seeds are major sources of magnesium necessary for the body. Also, they bring a substantial contribution of phosphorus, iron and manganese [20]. Hemp (Cannabis sativa L.) along with rape or spinach is among the plants appropriate for decontamination of soil contaminated with $\mathrm{Zn}$ and $\mathrm{Cd}$ [21]. Hemp mainly extracts $\mathrm{Ni}$ concentrating it in leaves, not so much in the seeds [15]. Hemp is great consumer of nutrients $(\mathrm{N}$, $\mathrm{P}, \mathrm{K})$, because during the growing season it develops a large vegetative mass and accumulates $70-75 \%$ of the dry matter in the first period of vegetation. The lignification process of the stem and the increase in resistance of the plant requires significant calcium intake. Potassium is also a key nutrient to ensure resistance to cold, drought and pests, but primary for the initial stage of seed formation. Magnesium is a component of oil and it contributes to the formation of hemp seeds [22-24]. Magnesium deficiency induces leaf chlorosis and the plants are small.

Manganese is an essential element in the activation of plant enzymes, it increases hemp plants resistance to drought and cold and helps to assimilate nitrogen from the soil. Increasing the concentration of manganese in the soil over $1500-3000 \mathrm{mg} \cdot \mathrm{kg}^{-1}$ induce over 300$350 \mathrm{mg} \cdot \mathrm{kg}^{-1}$ in the plant as a result of fertilization or due to pollution sources such as sewage sludges [24-26]. Excess manganese is found in acid soils ( $\mathrm{pH}$ less than 5.5), with low organic matter and excess water. Iron is another plant nutrient involved in nitrogen metabolism and photosynthesis. The concentration of iron minerals in different layers of soil is ranged between 100-100000 $\mu \mathrm{g} \cdot \mathrm{g}^{-1}$ [27]. Fe and Mn intake by hemp seed must be within the upper tolerable daily intakes (UL) level of 45-11 mg/day/person [28]. Zinc is the cofactor of many enzymes, proteins and influences the electronic transfer in Krebss cycle reactions affecting the plant's energy production. In accordance with the zinc transfer coefficient from soil to plants of 1-10 [29], the daily intake required by the plant is $70 \mathrm{mg} / \mathrm{g} \mathrm{Zn}$, and the critic one is $170 \mathrm{mg} / \mathrm{g}$ for soil containing $50-100 \mathrm{mg} / \mathrm{g}$ [30]. The recommended daily intake for adults is $8-11 \mathrm{mg} \mathrm{Zn} /$ day and an excess reduces the levels of high density lipoproteins and reduces the immune function [28]. Cadmium in soil poses a risk both for human receptors, as well as for the ecological ones, because of its relatively high toxicity and uptake in plants. $\mathrm{Cd}$ binds rapidly to the intra and extra cellular proteins, leading to the rupture of cell membranes and to the stoppage of the cells functions. As the most important natural cadmium sources we can mention integral cereal, potatoes and seafood. As a result maximum admitted cadmium content in cereal is $100 \mu \mathrm{g} \cdot \mathrm{kg}^{-1}$ and in medicinal plants $300 \mu \mathrm{g} \cdot \mathrm{kg}^{-1}[19]$. The medium Cd content in soil is of $0.5-0.8 \mathrm{mg} \cdot \mathrm{kg}^{-1}$, and the maximum limit admitted for the total content of $\mathrm{Cd}$ tolerated by the plants is between $3-5 \mathrm{mg} \cdot \mathrm{kg}^{-1}$, while in Romania the maximum concentration of $\mathrm{Cd}$ allowed in soil is $1 \mathrm{mg} \cdot \mathrm{kg}^{-1}[8,29,31,32]$.

\section{Results and discussion}

\section{Oil content and fatty acids from whole hemp seeds}

Table 1 presents the content of oil in analyzed monoic (Zenit, Diana, Denise) and dioic (Armanca, Silvana) hemp seeds obtained on parcels non fertilized $\mathrm{N}_{0} \mathrm{P}_{0} \mathrm{~K}_{0}$ with a seeding spacing of $20 \mathrm{~cm}$, in 2011 yield. The average content of oil in whole seeds of the Romanian hemp varieties analyzed is of $27.81 \%$ of the biological material used in planting and $23.89 \%$ for the production obtained 
Table 1 Oil content ${ }^{*}(\%)$ in hemp seed varieties and iodine value

\begin{tabular}{|c|c|c|c|c|c|c|}
\hline \multicolumn{2}{|l|}{ Samples } & \multirow{2}{*}{$\begin{array}{c}\text { Zenit } \\
27.37 \pm 0.11\end{array}$} & \multirow{2}{*}{$\begin{array}{c}\text { Diana } \\
26.54 \pm 0.22\end{array}$} & \multirow{2}{*}{$\begin{array}{c}\text { Denise } \\
26.96 \pm 0.06\end{array}$} & \multirow{2}{*}{$\begin{array}{c}\text { Armanca } \\
29.27 \pm 0.37\end{array}$} & \multirow{2}{*}{$\begin{array}{c}\text { Silvana } \\
28.89 \pm 0.08\end{array}$} \\
\hline Oil content $\%(w / w)$ & 2010 & & & & & \\
\hline & 2011 & $22.97 \pm 0.96$ & $20.82 \pm 0.85$ & $25.30 \pm 0.14$ & $25.32 \pm 1,21$ & $25.04 \pm 0.34$ \\
\hline lodine value & & $140.5 \pm 1.50$ & $141.3 \pm 1.24$ & $144.4 \pm 1.41$ & $155.5 \pm 1.62$ & $150.6 \pm 1.36$ \\
\hline \multicolumn{7}{|l|}{ (g of $\mathrm{I}_{2} / 100 \mathrm{~g}$ of oil) } \\
\hline \multirow{2}{*}{\multicolumn{2}{|c|}{ lodine value from the literature ( $\mathrm{g}$ of $\mathrm{I}_{2} / 100 \mathrm{~g}$ of oil) }} & & & $140-172^{* *}$ & & \\
\hline & & & & $154-165^{* * *}$ & & \\
\hline
\end{tabular}

*Values are means \pm SD of five hemp (C. sativa) oils, analyzed individually in triplicate.

***Tabără, V, 2005 [41].

***Anwar et al. (2006) [42].

in 2011. These values are slightly lower than the ones of $30-35 \%$ reported in literature $[1,20,33]$. The high monthly average temperatures $\left(25-26^{\circ} \mathrm{C}\right)$ during the flourishing period and low rainfall level of $223 \mathrm{~mm}$, result in an incomplete maturation of seeds and a decrease in oil content. Relative weight of 1000 seeds varies between 17 and $23 \mathrm{~g}$ and germination properties between $80-90 \%$. The dioecious varieties have a higher oil content. The high content of unsaturated fatty acid in hemp oil is reflected in the value of the iodine index of over $140 \mathrm{~g} \mathrm{I}_{2} / 100 \mathrm{~g}$ oil.

\section{Metal content in soil and hemp seeds}

The experimental site is located in the steppe zone with a high hidrostatic level of phreatic water represented by slightly salted chernozems, weakly acid on areas, and well supplied with phosphorus, humus, nitrogen and potassium. The levels of soil metals $(\mathrm{Ca}, \mathrm{Mg}, \mathrm{K}, \mathrm{Fe}, \mathrm{Mn}$, $\mathrm{Zn}$ and $\mathrm{Cd}$ ) from these areas are presented in Table 2. From total content of metals in soil, only a small part is available. Metal availability strongly depends on $\mathrm{pH}$, which is influenced by the level of mineral fertilization. Calcium is present in adequate amounts in most soils. Calcium is a component of several primary and secondary minerals in the soil, which are essentially insoluble for agricultural considerations. These materials are the original sources of the soluble or available forms of Ca.
Calcium is also present in relatively soluble forms, as a cation (positively charged $\mathrm{Ca}^{++}$) adsorbed to the soil colloidal complex. The ionic form is considered to be available to crops. Acid soils have less $\mathrm{Ca}$, and high $\mathrm{pH}$ soils normally have more. As the soil $\mathrm{pH}$ increases above $\mathrm{pH}$ 7.2, due to additional soil $\mathrm{Ca}$, the additional "free" $\mathrm{Ca}$ is not adsorbed onto the soil [34]. Much of the free Ca forms nearly insoluble compounds with other elements such as phosphorus ( $\mathrm{P})$, thus making $\mathrm{P}$ less available. Being a major cation, calcium availability is related to the soil cation exchange capacity (CEC), and it is in competition with other major cations such as sodium $\left(\mathrm{Na}^{+}\right)$, potassium $\left(\mathrm{K}^{+}\right)$, magnesium $\left(\mathrm{Mg}^{++}\right)$, ammonium $\left(\mathrm{NH}_{4}^{+}\right)$, iron $\left(\mathrm{Fe}^{++}\right)$, and aluminum $\left(\mathrm{Al}^{+++}\right)$for uptake by the crop. High $\mathrm{K}$ applications have been known to reduce the Ca uptake in plant. The soil on which fiber hemp was cultivated has medium available calcium content (Table 2). Fiber hemp does not have high requirements for calcium, the quantity found in soil is sufficient for hemp nutrition. The highest calcium content of hempseed was found in Zenit variety (9547 mg.kg ${ }^{-1}$ ), while the lower was found in Armanca variety (1440 mg. $\mathrm{kg}^{-1}$ ) (Figure 1). In Zenit and Silvana variety, fertilization with Fertileader Viti B:P:K=1:6:12 (factor- $b_{2}$ ) leads to highest calcium content of hempseed. In Diana variety the highest calcium content was determined in unfertilized variant. In this case absorption of potassium

Table 2 Content of Ca, Mg, $\mathrm{K}$ and heavy metals (Fe, Mn, Zn and Cd) of gleyed chernozem moderately low on hemp cultivation area dioecious and monoecious hemp

\begin{tabular}{lllll}
\hline $\begin{array}{l}\mathbf{N r} \\
\mathbf{c r t}\end{array}$ & $\begin{array}{l}\text { Elemente } \\
\mathbf{m g ~ K g}^{-1}\end{array}$ & $\begin{array}{l}\text { Gleyed chernozem moderately weak } \\
\text { dioecious hemp cultivation area }\end{array}$ & $\begin{array}{l}\text { Gleyed chernozem moderately weak } \\
\text { monoecious hemp cultivation area }\end{array}$ & $\begin{array}{l}\text { Normal metal contents, } \\
\text { for Romania (NC) }^{*} \text { mgKg }^{-1}\end{array}$ \\
\hline 1 & $\mathrm{Ca}$ & 2100 & 2520 & - \\
2 & $\mathrm{Mg}$ & 320 & 376 & - \\
3 & $\mathrm{~K}$ & 232 & 257 & - \\
4 & $\mathrm{Fe}$ & 19100 & 20430 & - \\
5 & $\mathrm{Mn}$ & 156 & 197 & 900 \\
6 & $\mathrm{Zn}$ & 54 & 67 & 100 \\
7 & $\mathrm{Cd}$ & 3,77 & 3,23 & 1 \\
\hline
\end{tabular}

*Order 756 from 16.08.2004 [32]. 


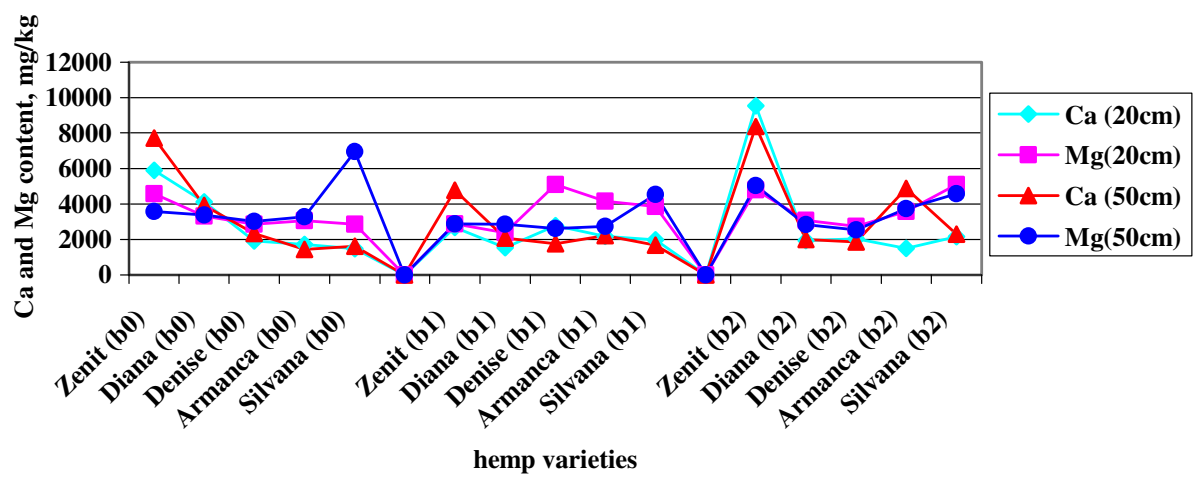

Figure $1 \mathrm{Ca}$ and $\mathrm{Mg}$ content in hempseed varieties under fertilization (b0, b1, b2) and seeding space $(20 \mathrm{~cm}, 50 \mathrm{~cm})$.

applied as foliar fertilizer could block calcium absorption in hemp and lead to low calcium content of hemp seed.

Using the $\mathrm{F}$ test $\left(\mathrm{F}_{(4,24)}=26.5, \mathrm{p}<0.05, \mathrm{~F}_{5 \%}=2.78\right)$ it can be observed that the variety and the fertilization interaction with the variety $\left(\mathrm{F}_{(8,24)}=4.1, \mathrm{p}<0.05, \mathrm{~F}_{5 \%}=2.34\right)$ determines significant differences in the $\mathrm{Ca}$ content from the studied hemp seeds.

By comparing the two average concentrations of $\mathrm{Ca}$ in the seeds corresponding to the $\mathrm{B}$ independent variable (treatment) statistically significant differences are observed between the average Ca content from hemp seeds under the effects of fertilization with N87:P96:K0 $+3 \mathrm{Kg} / \mathrm{ha}$ Corona (factor-b $\mathrm{b}_{1}$ ) and N68:P64:K16+ $3 \mathrm{~L} / \mathrm{ha}$ Fertileader Viti (factor- $b_{2}$ ) (Table 3).

Magnesium is a component of several primary and secondary minerals in the soil, which are essentially insoluble, for agricultural considerations. These materials are the original sources of the soluble or available forms of Mg. Magnesium is also present in relatively soluble forms, and is found in ionic form $\left(\mathrm{Mg}^{++}\right)$retained to the soil colloidal complex. The ionic form is considered to be available to crops. Being a major cation, $\mathrm{Mg}$ availability is related to the soil CEC, and it is in competition with other major cations such as calcium $\left(\mathrm{Ca}^{++}\right)$, potassium $\left(\mathrm{K}^{+}\right)$, sodium $\left(\mathrm{Na}^{+}\right)$, ammonium $\left(\mathrm{NH} 4^{+}\right)$, iron $\left(\mathrm{Fe}^{++}\right)$, and aluminum $\left(\mathrm{Al}^{+++}\right)$. It appears that potassium is a stronger competitor with $\mathrm{Mg}$ than it is sometimes considered to be. Cambic chernozem on which experiments were made has good magnesium supply, ranged between $320-376 \mathrm{mg} \cdot \mathrm{kg}^{-1}$. Ideal soil Ca:Mg ratio range between 5:1 and 8:1. Like in calcium case, Zenit variety, Armanca variety at $50 \mathrm{~cm}$ and Silvana variety at $20 \mathrm{~cm}$ had a higher magnesium content after fertilization with Fertileader Viti B:P:K=1:6:12. Diana variety, Denise variety at $50 \mathrm{~cm}$ and Silvana variety at $50 \mathrm{~cm}$ have the highest magnesium content in unfertilized variant. Although soil has a good magnesium supply, its uptake could be disturbed by calcium and potassium presence in soil. Application of Corona K (N:P:K=8:11:39) fertilizer lead to highest magnesium content in hempseed Denise and Armanca variety at $20 \mathrm{~cm}$ (Figure 1).

The statistical processing by the ANOVA method of the $\mathrm{Mg}$ results generated in the trifactorial experience with three repetitions shows the effects of the variety on the $\mathrm{Mg}$ content in the seeds. The average Mg content in the Silvana seeds is significantly higher thant the concentration in the Diana, Denise and Armanca varieties. Changing the treatment and the seeding spacing doesn't produce significant differences of the Mg concentration in hemp seeds.

Plant-available soil $\mathrm{K}$ is in the ionic (electrically charged) form. This charge is positive, making $\mathrm{K}$ a cation, represented as $\mathrm{K}^{+}$. Cations are attracted to, and held by negatively charged colloids (primarily clay and organic matter) that make up the cation exchange capacity (CEC) of the soil. The larger the CEC, the more K can be held by the soil and the more adequate it is for the plants. There are occasions when $\mathrm{K}$ uptake might be restricted due to an imbalance with other cation elements in the soil. For example, in many high $\mathrm{pH}$ soils there is an excess of $\mathrm{Ca}$. Competition between $\mathrm{Ca}$ and $\mathrm{K}$ could reduce potassium uptake. Strongly acid soils will often have an excess of hydrogen $(\mathrm{H})$, aluminum (Al), iron $(\mathrm{Fe})$, and possibly other cation elements. These excess elements can compete with $\mathrm{K}$ for entry into the plant, and/or set up soil conditions that are unfavorable to efficient $\mathrm{K}$ utilization. It is generally accepted that there are some preferred general relationships and balances between soil nutrients. There is also a significant amount of work indicating that excesses and shortages of some nutrients will affect the uptake of other nutrients. Ideal ratio between $\mathrm{Ca}, \mathrm{Mg}$ and $\mathrm{K}$ in soil is: $\mathrm{Ca}: \mathrm{K}$ of 13:1, and Mg:K of 2:1. Soil used in experience has cation ratio thereabouts ideal. Potassium takes part in the formation of carbohydrates, enhances the sap's circulation and creates hemp's resistance to drought. Potassium excess enhances the autothinning phenomenon and increases the crop losses [35]. Potassium plays a vital 
Table 3 Metal content for five varieties hemp seed under influence fertilization and seeding distance $\left(\mathrm{mg}^{\mathrm{kg}} \mathrm{kg}^{-1}\right)$

\begin{tabular}{|c|c|c|c|c|c|c|c|c|c|c|c|}
\hline \multirow{2}{*}{$\begin{array}{l}\text { Factor A-variety } \\
\mathrm{Ca} \pm \mathrm{SD}\end{array}$} & \multicolumn{2}{|l|}{ Zenit } & \multicolumn{2}{|l|}{ Diana } & \multicolumn{2}{|l|}{ Denise } & \multicolumn{2}{|l|}{ Armanca } & \multicolumn{2}{|l|}{ Silvana } & 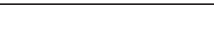 \\
\hline & & & & & & & & & & & \\
\hline Fertilization & $20 \mathrm{~cm}$ & $50 \mathrm{~cm}$ & $20 \mathrm{~cm}$ & $50 \mathrm{~cm}$ & $20 \mathrm{~cm}$ & $50 \mathrm{~cm}$ & $20 \mathrm{~cm}$ & $50 \mathrm{~cm}$ & $20 \mathrm{~cm}$ & $50 \mathrm{~cm}$ & Average -factor $B$ \\
\hline$b_{0}$ & $5887 \pm 356$ & $7707 \pm 321$ & $4120 \pm 151$ & $3907 \pm 299$ & $1913 \pm 95$ & $2327 \pm 239$ & $1713 \pm 101$ & $1440 \pm 68$ & $1473 \pm 53$ & $1620 \pm 63$ & 3211 \\
\hline$b_{1}$ & $2667 \pm 163$ & $4780 \pm 284$ & $1533 \pm 109$ & $2067 \pm 152$ & $2773 \pm 130$ & $1753 \pm 71$ & $2180 \pm 98$ & $2213 \pm 142$ & $1973 \pm 91$ & $1687 \pm 41$ & $2363^{*}$ \\
\hline$b_{2}$ & $9547 \pm 341$ & $8360 \pm 329$ & $1933 \pm 180$ & $2000 \pm 173$ & $2040 \pm 140$ & $1866 \pm 84$ & $1507 \pm 91$ & $4873 \pm 377$ & $2147 \pm 117$ & $2293 \pm 119$ & $3657^{*}$ \\
\hline Average factor A & \multicolumn{2}{|c|}{6491} & \multicolumn{2}{|c|}{2593} & \multicolumn{2}{|c|}{2112} & \multicolumn{2}{|c|}{2321} & \multicolumn{2}{|c|}{1866} & \\
\hline \multicolumn{12}{|c|}{ maximum allowable limits MAL- Ca unregulated } \\
\hline \multicolumn{12}{|l|}{$\mathrm{Mg} \pm \mathrm{SD}$} \\
\hline$b_{0}$ & $4573 \pm 258$ & $3567 \pm 271$ & $3313 \pm 194$ & $3367 \pm 372$ & $2847 \pm 93$ & $3020 \pm 110$ & $3060 \pm 66$ & $3273 \pm 110$ & $2853 \pm 185$ & $6940 \pm 641$ & 3681 \\
\hline$b_{1}$ & $2880 \pm 139$ & $2880 \pm 168$ & $2373 \pm 173$ & $2860 \pm 238$ & $5093 \pm 579$ & $2607 \pm 73$ & $4153 \pm 145$ & $2727 \pm 271$ & $3860 \pm 231$ & $4540 \pm 406$ & 3397 \\
\hline$b_{2}$ & $4793 \pm 325$ & $5033 \pm 267$ & $3080 \pm 123$ & $2833 \pm 139$ & $2733 \pm 142$ & $2533 \pm 104$ & $3567 \pm 240$ & $3740 \pm 186$ & $5093 \pm 137$ & $4580 \pm 92$ & 3799 \\
\hline Average factor A & \multicolumn{2}{|c|}{3954} & \multicolumn{2}{|c|}{$2971^{* *}$} & \multicolumn{2}{|c|}{$3139^{* *}$} & \multicolumn{2}{|c|}{$3420^{*}$} & \multicolumn{2}{|c|}{$4644^{* *}$} & \\
\hline \multicolumn{12}{|c|}{ maximum allowable limits MAL - Mg unregulated } \\
\hline \multicolumn{12}{|l|}{$\mathrm{K} \pm \mathrm{SD}$} \\
\hline$b_{0}$ & $21260 \pm 1127$ & $28207 \pm 1589$ & $6820 \pm 258$ & $5953 \pm 144$ & $5273 \pm 168$ & $6427 \pm 329$ & $7127 \pm 475$ & $7967 \pm 423$ & $7327 \pm 335$ & $19787 \pm 2018$ & 11615 \\
\hline$b_{1}$ & $20007 \pm 1141$ & $9960 \pm 482$ & $4627 \pm 442$ & $5733 \pm 267$ & $9040 \pm 418$ & $5213 \pm 320$ & $13007 \pm 1078$ & $7460 \pm 235$ & $9880 \pm 491$ & $13520 \pm 955$ & 9845 \\
\hline$b_{2}$ & $20860 \pm 1257$ & $13087 \pm 1700$ & $5260 \pm 286$ & $5767 \pm 375$ & $5207 \pm 353$ & $5300 \pm 481$ & $8980 \pm 314$ & $14900 \pm 1181$ & $12653 \pm 1171$ & $10500 \pm 887$ & 10251 \\
\hline Average factor A & \multicolumn{2}{|c|}{18897} & \multicolumn{2}{|c|}{5693} & \multicolumn{2}{|c|}{6077} & \multicolumn{2}{|c|}{9907} & \multicolumn{2}{|c|}{12278} & \\
\hline \multicolumn{12}{|c|}{ maximum allowable limits MAL- $K$ unregulated } \\
\hline \multicolumn{12}{|l|}{$\mathrm{Fe} \pm \mathrm{SD}$} \\
\hline$b_{0}$ & $2000 \pm 148$ & $2400 \pm 237$ & $1700 \pm 84$ & $1680 \pm 90$ & $1740 \pm 49$ & $1667 \pm 115$ & $1593 \pm 35$ & $1620 \pm 67$ & $1630 \pm 42$ & $1587 \pm 62$ & 1762 \\
\hline$b_{1}$ & $1620 \pm 36$ & $1133 \pm 79$ & $1767 \pm 105$ & $1680 \pm 99$ & $1740 \pm 102$ & $1580 \pm 115$ & $1580 \pm 135$ & $1640 \pm 114$ & $1560 \pm 59$ & $1540 \pm 46$ & 1584 \\
\hline$b_{2}$ & $1600 \pm 95$ & $2400 \pm 224$ & $1720 \pm 67$ & $1700 \pm 81$ & $1660 \pm 67$ & $1660 \pm 74$ & 158086 & $1620 \pm 66$ & $1647 \pm 120$ & $1610 \pm 135$ & 1720 \\
\hline Average factor A & & & & & & & & & & & \\
\hline maximum allowabl & limits MAL- Fe & hregulated & & & & & & & & & \\
\hline $\mathrm{Mn} \pm \mathrm{SD}$ & & & & & & & & & & & \\
\hline$b_{0}$ & $97 \pm 3.7$ & $69 \pm 2.2$ & $80 \pm 7.6$ & $86 . \pm 9.3$ & $99 \pm 5.5$ & $90 \pm 4.04$ & $86 \pm 2.7$ & $81 \pm 3.3$ & $86 \pm 3.8$ & $96 \pm 7.6$ & 87 \\
\hline$b_{1}$ & $75 \pm 5.9$ & $63 \pm 0.9$ & $94 \pm 4.7$ & $95 \pm 10.2$ & $106 \pm 4.3$ & $84 \pm 3.2$ & $75 \pm 1.6$ & $75 \pm 4.5$ & $83 \pm 4.8$ & $83 \pm 8.7$ & 83 \\
\hline$b_{2}$ & $64 \pm 2.6$ & $64 \pm 3.0$ & $95 \pm 5.5$ & $98 \pm 7.9$ & $110 \pm 8.6$ & $85 \pm 6.9$ & $81 \pm 3.2$ & $76 \pm 4.6$ & $84 \pm 2.3$ & $84 \pm 2.4$ & 85 \\
\hline Average factor A & & & & & & & & & & & \\
\hline
\end{tabular}


Table 3 Metal content for five varieties hemp seed under influence fertilization and seeding distance (mg.kg $\left.{ }^{-1}\right)$ (Continued)

maximum allowable limits MAL-Mn 300-350 mg.kg ${ }^{-1}$

\section{$\mathrm{Zn} \pm \mathrm{SD}$}

$b_{0}$

$\begin{array}{ll}62 \pm 3.7 & 50 \pm 2.4 \\ 42 \pm 2.8 & 47 \pm 2.5 \\ 49 \pm 4.0 & 46 \pm 4.3\end{array}$

$94 \pm 6.2$
$56 \pm 3.0$
$60 \pm 4.6$

$$
53 \pm 2.3
$$

$58 \pm 4.7$

$58 \pm 4.9$

$62 \pm 2.7$

$$
56 \pm 2.5
$$

$59 \pm 3.2$

$65 \pm 3.5$

$53 \pm 2.2$

$60 \pm 5.0$

Average factor $A$

51

64

59

$\begin{array}{ll}71 \pm 3.3 & 70 \pm 6.7 \\ 76 \pm 5.8 & 60 \pm 6.3 \\ 66 \pm 4.3 & 65 \pm 4.2\end{array}$

$67 \pm 3.5$

$78 \pm 5.5$

maximum allowable limits MAL- Zn 170 mg. $\mathrm{kg}^{-1}$

\begin{tabular}{|c|c|c|c|c|c|c|c|c|c|c|}
\hline$b_{0}$ & $1.3 \pm 0.27$ & $2.0 \pm 0.11$ & $4.0 \pm 0.13$ & $3.3 \pm 0.31$ & $3.3 \pm 0.47$ & $2.7 \pm 0.20$ & $3.3 \pm 0.21$ & $3.3 \pm 0.13$ & $3.3 \pm 0.12$ & $3.3 \pm 0.20$ \\
\hline$b_{1}$ & $2.0 \pm 0.05$ & $2.0 \pm 0.23$ & $2.0 \pm 0.06$ & $2.7 \pm 0.13$ & $2.7 \pm 0.17$ & $2.7 \pm 0.06$ & $3.3 \pm 0.31$ & $4.0 \pm 0.30$ & $4.0 \pm 0.32$ & $4.0 \pm 0.38$ \\
\hline$b_{2}$ & $2.0 \pm 0.15$ & $2.0 \pm 0.18$ & $3.3 \pm 0.21$ & $2.7 \pm 0.10$ & $4.0 \pm 0.33$ & $3.3 \pm 0.26$ & $3.3 \pm 0.06$ & $3.3 \pm 0.08$ & $2.7 \pm 0.08$ & $3.3 \pm 0.27$ \\
\hline Average factor $\mathrm{A}$ & & & & & & & & & & \\
\hline
\end{tabular}

$\mathrm{Cd} \pm \mathrm{SD}$

maximum allowable limits MAL $-\mathrm{Cd} 0.300 \mathrm{mg} \cdot \mathrm{kg}^{-1}$

Values are means \pm SD of five hemp seed (C. sativa) varieties, analyzed individually in triplicate. 
role in: photosynthesis, translocation of photosynthates, protein synthesis, control of ionic balance, regulation of plant stomata and water use, activation of plant enzymes and, many other processes. Potassium is also known as the quality nutrient because of its important effects on quality factors such as size, shape, fiber quality and other quality measurements. The highest potassium content was determined in Zenit variety in unfertilized variant (21260 mg. $\mathrm{kg}^{-1}$ in $20 \mathrm{~cm}$ and $28207 \mathrm{mg} \cdot \mathrm{kg}^{-1}$ in $50 \mathrm{~cm}$ ) (Figure 2). Fertilization with both fertilizers gave different results concerning potassium accumulation in hempseeds. Potassium uptake by plants is affected by several factors. Higher soil moisture usually means greater availability of $\mathrm{K}$. Increasing soil moisture increases movement of $\mathrm{K}$ to plant roots and enhances availability. Researches has generally shown more responses to $\mathrm{K}$ fertilization in dry years. Air is necessary for root respiration and $\mathrm{K}$ uptake. Root activity and subsequent $\mathrm{K}$ uptake decrease as soil moisture content increases to saturation. Root activity, plant functions, and physiological processes all increase as soil temperature increases. This increase in physiological activity leads to increased $\mathrm{K}$ uptake. Availability of soil $\mathrm{K}$ is reduced in no-till and ridge-till planting systems. The exact cause of this reduction is not known. Results of research point to restrictions in root growth combined with a restricted distribution of roots in the soil.

The experimental values $\mathrm{F}$ calculated for the separate action of the factors and their interaction in this experiment proves the fact that the variety $\left(\mathrm{F}_{(4,24)}=17.8\right.$, $\left.\mathrm{p}<0.05 ; \mathrm{F}_{1 \%}=4.22\right)$ and the variety's interaction with the seeding distance $\left(\mathrm{F}_{(4,30)}=4.4, \mathrm{p}<0.05 ; \mathrm{F}_{1 \%}=4.02\right)$ have a significant influence on the $\mathrm{K}$ content from the analyzed seed samples.

After the use of the Tukey test the differences of the $\mathrm{K}$ concentration are considered significant for the Armanca-Denise $\left({ }^{*}\right)$, high significant for the Armanca-Diana (**) and extremely significant for the Silvana -Diana and Silvana -Denise ${ }^{(* * * *)}$ using as control the Zenit variety.

Iron content of cambic chernozem is ranged between 19000 and $20430 \mathrm{mg} \cdot \mathrm{kg}^{-1}$, which means a good soil supply.
Iron content of hempseed is relatively uniform in all varieties. Differences between fertilization variants are insignificant. Although the highest iron content was observed in Zenit variety (Figure 3). Iron uptake in hemp is inhibited by excessive amounts of soluble $\mathrm{P}$, or high rates of $\mathrm{P}$ fertilizer. Increased $\mathrm{NO}_{3}-\mathrm{N}$ uptake in plant due to fertilization can reduce Fe uptake by causing an anioncation imbalance in the plant. Zn deficiency has been shown to increase the Fe uptake of many crops, sometimes to the point of toxicity. Conversely, high $\mathrm{Zn}$ availability reduces Fe uptake. It is well documented that iron and manganese are antagonistic, and one will inhibit the uptake of the other. $\mathrm{K}$ appears to play a very specific, but poorly understood role in the utilization of Fe by fiber hemp. Some research indicates that low $\mathrm{K}$ availability can result in increased Fe uptake in plant.

After the analysis of variance for the separate action and interaction of the factors it can be observed that neither the variety nor the seeding distance or the applied treatments have no influence on the Fe concentration in studied the hemp seeds.

Zinc content of soil is medium (Table 2), cambic chernozem having a good supply in organic matter which can chelate inorganic sources of $\mathrm{Zn}$ and increase their availability to fiber hemp. Zinc availability to hemp can be decreased by phosphorus fertilization. Plant roots appear to absorb $\mathrm{Zn}$ and $\mathrm{Cu}$ by the same mechanism. This causes interference in the uptake of one when the other is in excess in the root zone. Application of Fertileader Viti B:P:K=1:6:12 fertilizer lead to a decrease of zinc content in all hemp varieties, excepting Denise variety. In Zenit and Silvana variety and also in Diana variety at $20 \mathrm{~cm}$, highest zinc content of hempseed was calculated in unfertilized variant. In this varieties application of fertilizers containing phosphorus inhibited zinc absorption by plant and its translocation to seeds. In only one variant, Armanca variety at $20 \mathrm{~cm}$, application of Corona $\mathrm{K}$ $(\mathrm{N}: \mathrm{P}: \mathrm{K}=8: 11: 39)$ fertilizer containing zinc, lead to increase of zinc content.

By examining the factors and their interaction in the ANOVA factorial test of the $\mathrm{Zn}$ concentrations, it can be

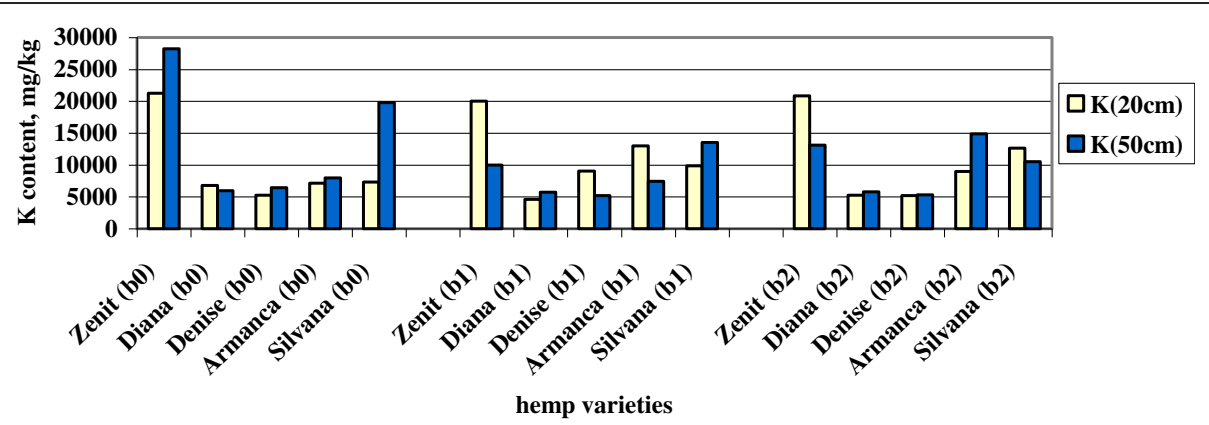

Figure $2 \mathrm{~K}$ content in hempseed varieties under fertilization (b0, b1, b2) and seeding space $(20 \mathrm{~cm}, 50 \mathrm{~cm})$. 


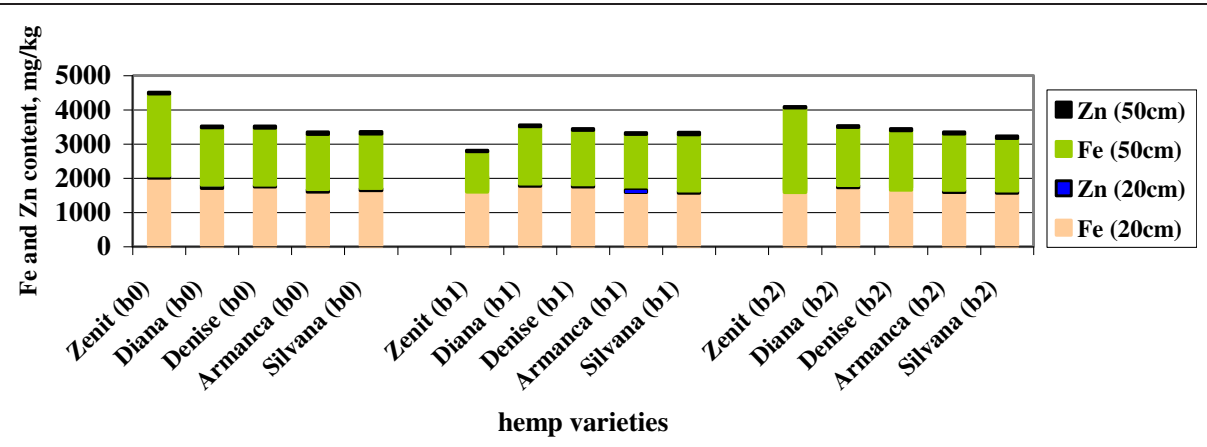

Figure $3 \mathrm{Fe}$ and $\mathrm{Zn}$ content in hempseed varieties under fertilization (b0, b1, b2) and seeding space $(20 \mathrm{~cm}, 50 \mathrm{~cm})$.

observed that the F values calculated are smaller that the theoretical ones $\mathrm{F}_{5 \%}$. So the differences between the averages are insignificant.

Comparing the $\mathrm{Zn}$ content in two varieties by the limit differences bring to attention the Zenit variety which has lower Zn content than Armanca and Silvana (*).

Manganese content of experimental soil is low. Mn can be "tied up" by the organic matter such that high $\mathrm{O}$. M. soils, like cambic chernozem, can be Mn deficient. Also soils high in available iron, or high iron applications can reduce $\mathrm{Mn}$ uptake in hemp plant. The lowest manganese content was determined in Zenit variety, after fertilization with Fertileader Viti B:P:K=1:6:12. Manganese content higher than $14 \mathrm{ppm}$ is determined in Diana variety in both fertilization variants and in Silvana variety in $50 \mathrm{~cm}$, unfertilized variant. Because of the soil low manganese content, most of the plant manganese comes from applied fertilizers (Figure 4). In varieties were highest content was determined in unfertilized plot, application of fertilizers containing phosphorus and potassium may inhibited manganese uptake by plants

As a conclusion for the statistical data determined through the ANOVA 5 $3 \times 2$ technique, the different components of the independent variable (variety, fertilization and seeding distance) and their interaction doesn't influence significantly the Mn content in the analyzed hemp seeds.
The F ratio of the independent variable and their interaction on the Mn content isn't significant statistically, so as a result there aren't differences between the averages of these variables.

Cadmium is a heavy metal known to have harmful effects on soil microorganisms and plants [36]. Experimental soil has higher content of cadmium, than admitted limit in soil (Table 2). Cadmium is often included in the fertilizer as a component of the phosphate component of the fertilizer. Removal of cadmium from the phosphate is considered expensive and rarely undertaken, so one of the cadmium source in soil could be fertilizers. The average content of $\mathrm{Cd}$ in the hemp seeds is ranged between $1.9 \mathrm{mg} \cdot \mathrm{kg}^{-1}$ (Zenit) and $3.4 \mathrm{mg} \cdot \mathrm{kg}^{-1}$ for the Armanca and Silvana varieties.

Under the action of fertilization the Silvana and Zenit varieties show growths of the cadmium content of between 20 and 50\% in the seeds of an N87:P96:K0 agrofield with Corona foliar fertilizer against an unfertilized one $b_{0}$ (Figura 5).

After the analysis of variance (ANOVA one-way) with dependent variable of $\mathrm{Cd}$ showed that the variety, as an influence factor and the interaction of the variety with the seeding distance determines statistically highly significant differences $(* *)$ and extremely significant differences ${ }^{* * *}$ ) of the $\mathrm{Cd}$ content in the seeds.

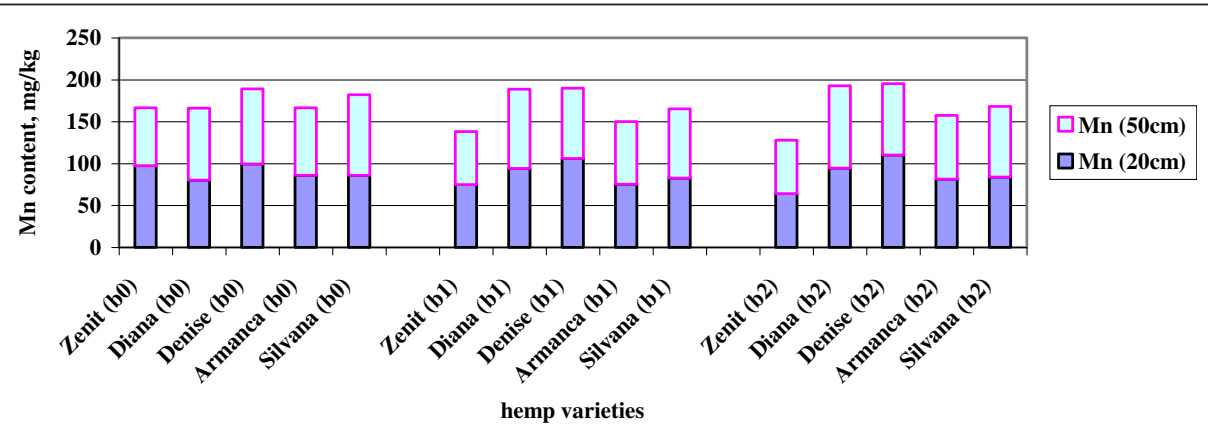

Figure $4 \mathrm{Mn}$ content in hempseed varieties under fertilization (b0, b1, b2) and seeding space $(20 \mathrm{~cm}, 50 \mathrm{~cm})$. 


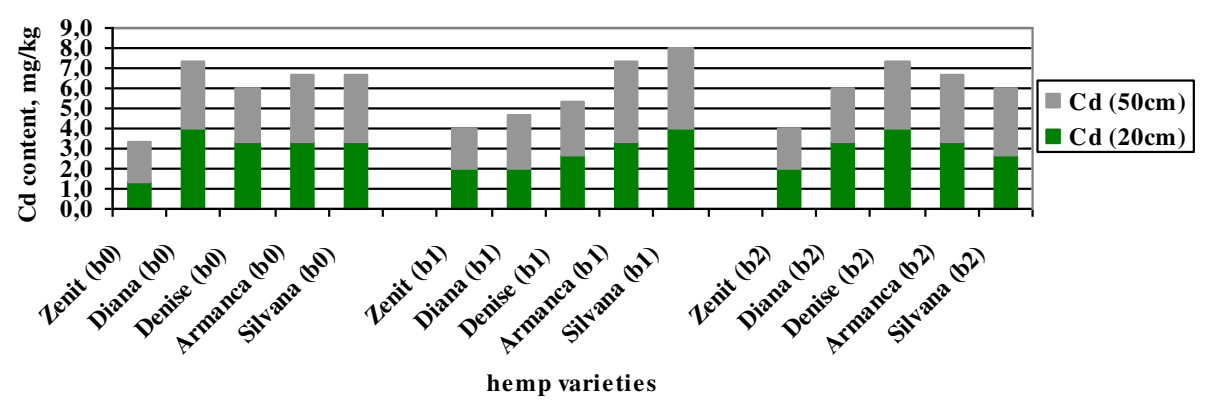

Figure $5 \mathrm{Cd}$ content in hempseed varieties under fertilization (b0,b1,b2) and seeding space $(20 \mathrm{~cm}, 50 \mathrm{~cm})$.

The researches made on typical chernozem soil moderately gleyed from Timisoara, at the same nitrogen doses, but in the presence of phosphorus and potassium fertilizers, at different levels, we observed a decrease of available content of $\mathrm{Zn}, \mathrm{Mn}, \mathrm{Cu}$ and $\mathrm{Ni}$ because of $\mathrm{pH}$ increase (that limit metal availability) and by the other hand, because of metal-phosphate combination which are forming in $\mathrm{P}$ excess condition. The most affected by mineral fertilization seems to be the available zinc content which decrease with almost $50 \%$ with increasing phosphorus and potassium doses. Available iron content increases with increasing the nitrogen, phosphorus and potassium. With increasing phosphorus and potassium doses, the available iron content decrease mainly because the formation of iron phosphates take place. The concentrations of monitored metals from hemp seeds studied under the influence of foliar fertilization and planting distance are found in Table 3.

\section{Conclusions}

The Romanian hemp varieties can be the base of a diet containing lots of oils an a large intake of fatty acids. The utilization of hemp seeds and hemp seed byproducts requires careful monitoring of metal content from soil and from the seeds. Hemp is one of the plants that extract easily metals such as Cadmium. P and $\mathrm{K}$ intake with foliar fertilizers like Fertileader Viti lightly enhances the average calcium concentration in seeds. Although over a certain value of $\mathrm{K}$ in soil the hemp will extract easier $\mathrm{K}$ cations instead of $\mathrm{Ca}$. The increase of the $\mathrm{K}$ content in seeds determines a growth in the $\mathrm{Mg}$ content so that the K:Mg ratio in the monoic and dioic unfertilized and fertilized seeds are to be maintained in certain limits. Neither fertilizing nor distance don't modify substantially the metal content such as $\mathrm{Fe}, \mathrm{Mn}, \mathrm{Zn}$ and $\mathrm{Cd}$ content.

\section{Experimental}

\section{Experimental site}

The experimental site is the Agricultural Research and Development Station in Lovrin, Timis area, located in the West of the Banat Plains, in the south west of Romania $\left(45.548^{\circ} \mathrm{N} / 20.461^{\circ} \mathrm{E}\right.$ (Figure 6). The agrochemical experiment took place in 2011 with five approved Romanian hemp varieties. The two experimental batches were placed in field under the form of a trifactorial experience, in divided plots, in three repetitions (Factor A- hempseed variety; Factor $\mathrm{B}$ - fertilization; Factor $\mathrm{C}$ - distance between plants $d=20 \mathrm{~cm}$ and $\mathrm{d}=50 \mathrm{~cm}$ ). Experimental lots as trifactorial experience in subdivided parcels, with dioecious hemp located on a typical chernozem soil moderately gleyed and the monoecious located in the north east of the village Lovrin to Pesac at a distance of $5 \mathrm{~km}$, near irrigation canal Aranca. The average temperature during the growing period of hemp (April-September 2011) was around $19.5^{\circ} \mathrm{C}$ and the precipitation level has been $223 \mathrm{~mm}$. The biological material used consists of three varieties of monoic hemp (Zenit, Denise and Diana) and two dioecious species (Armanca and Silvana). Two agrofields were achieved with complex fertilizers N16:P16: K16 and N18:P48:K0 using different doses, and $100 \mathrm{~kg} / \mathrm{ha}$ $\mathrm{NH}_{4} \mathrm{NO}_{3}$. The effect of foliar fertilization with $b_{1}-\mathrm{N} 87$ : P96:K0 + $3 \mathrm{~kg} / \mathrm{ha}$ Corona $\mathrm{K}(\mathrm{N}: \mathrm{P}: \mathrm{K}=8: 11: 39$ and $0,1 \% \mathrm{~B}+$ $0,1 \% \mathrm{Cu}+0,1 \% \mathrm{Fe}+0,1 \% \mathrm{Mn}+0,1 \% \mathrm{Zn})$ and $\mathrm{b}_{2}-\mathrm{N} 68: \mathrm{P} 64$ : K16 + 3 L/ha Fertileader Viti B:P:K=1:6:12 were followed up in comparison to the control unfertilized $b_{0}$ trials. Distance between rows was of $70 \mathrm{~cm}$ and the distance between plants was modified by $20-50 \mathrm{~cm}$. Seeding rate was of about $3-5 \mathrm{~kg} / \mathrm{ha}$.

\section{Samples collection and preparation}

Soil samples were taken from the two sites with dioecious respectively monoecious hemp. Soil samples are air dried, ground and sieved through a $2 \mathrm{~mm}$ sieve. Hemp seed samples were taken from experimentally obtained seed production on the unfertilized parcel associated with each variety at a distance of $20 \mathrm{~cm}$.

\section{Hempseed oil content}

Hemp seed oil extracted by Soxhlet method was with petroleum ether [37]. The fully automated Foss Soxtec 2055 system is used for fast and safe determinations of oil content of 6 samples of seed. Seed samples subjected 


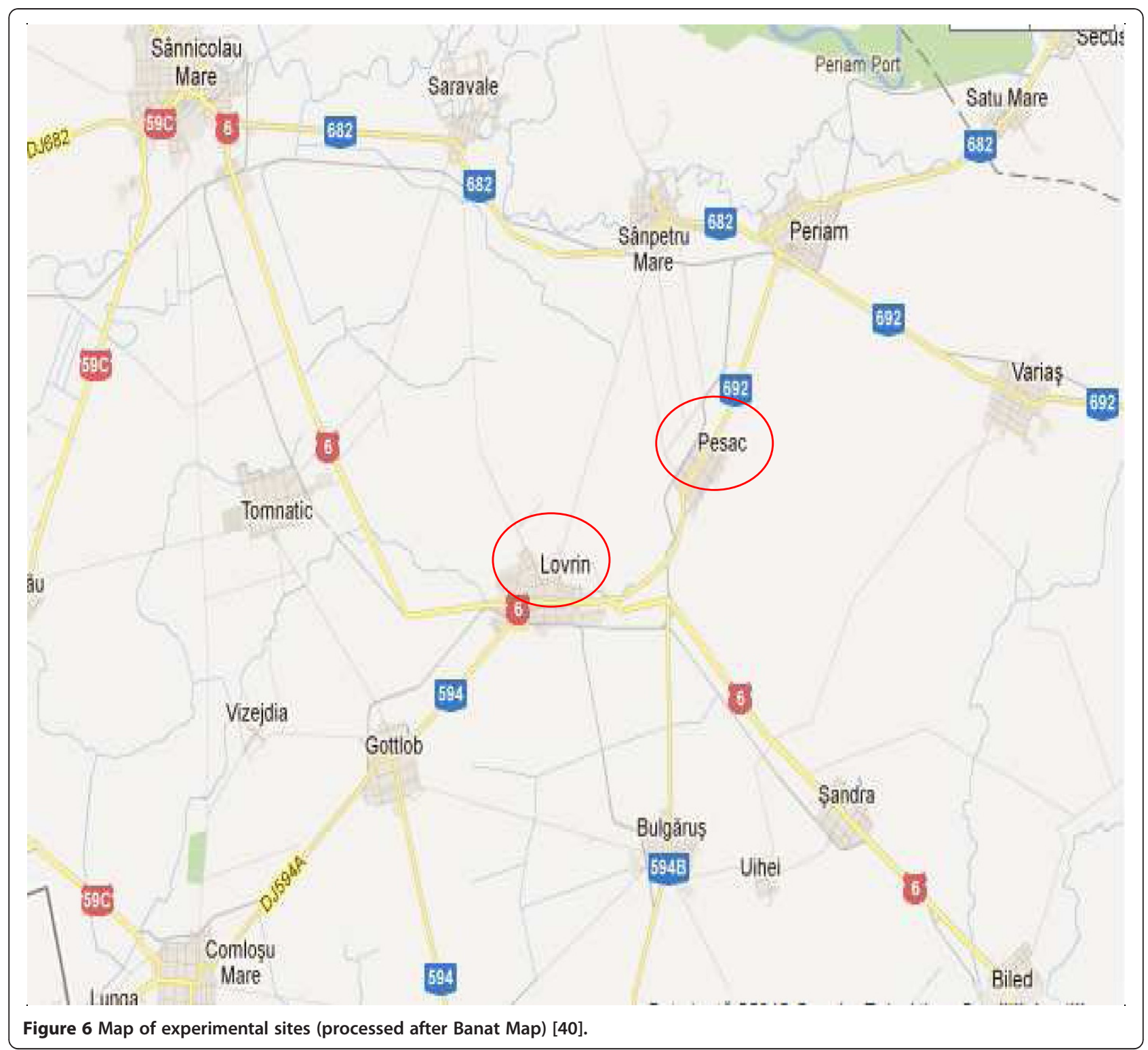

to extraction are from yields of the five varieties of hemp produced in 2011, on unfertilized plots and sown at 20 $\mathrm{cm}$, but also from the biological material used in seeding to achieve the experiment. Grind about $20 \mathrm{~g}$ of whole hemp seeds, mix and take three samples of $5.0 \mathrm{~g}$ powder which is subject to extraction with petrolium ether. Iodine value was determined in according by standard AOAC 920.158 methods [38].

\section{Macro and microelements content}

Soil samples, in three replicates for each variant, were air dried at room temperature, ground and sieved through a $2 \mathrm{~mm}$ sieve. From each soil sample $0.1 \mathrm{~g}$ was weight and subject it to mineralization with a mixture of $\mathrm{HNO}_{3}: \mathrm{HCl}=1: 3$ in the microwave with a method adapted after the 3050B method of the United
States Environmental Protection Agency [39]. After mineralization the sample is diluted to $50 \mathrm{~mL}$ volume with $0.5 \mathrm{~N} \mathrm{HNO}_{3}$.

Samples of $3 \mathrm{~g}$ of ground seed were burned $8 \mathrm{~h}$ at $550^{\circ} \mathrm{C}$ in furnace (Nabertherm B150, Lilienthal, Germany). The ash was dissolved in $\mathrm{HCl} 20 \%$ and are brought to $20 \mathrm{ml}$ in a volumetric flask.

The macroelements $(\mathrm{K}, \mathrm{Ca}, \mathrm{Mg})$ and microelements ( $\mathrm{Fe}, \mathrm{Cd}, \mathrm{Zn}$ and $\mathrm{Mn}$ ) were determined by AAS (Varian 220 FAA equipment). The standard solution for calibration curve were prepared by diluting the standards (1000 $\mathrm{mg} / \mathrm{L}$ ). Mix standard solutions (ICP Multielement Standard solution IV CertiPUR) were purchased from Merck. Double distilled water was used for the preparation of reagents and standards. Concentrate nitric acid $\left(\mathrm{HNO}_{3}\right.$ $65 \%)$, and concentrate $\mathrm{HCl}(37 \%)$, were obtained from 
Merck Germany. All chemicals were trace metal grade (Suprapur).

Method detection limits (MDL mg/L) for analyzed elements were: $0.02 \mathrm{mg} / \mathrm{L}$ for $\mathrm{Mg}$ and $\mathrm{K} ; 0.06 \mathrm{mg} / \mathrm{L}$ for Fe; $0.03 \mathrm{mg} / \mathrm{L}$ for $\mathrm{Ca} ; 0.04 \mathrm{mg} / \mathrm{L}$ for $\mathrm{Zn} ; 0.01 \mathrm{mg} / \mathrm{L}$ for $\mathrm{Cd}$ and $\mathrm{Mn}$. The average recoveries $\pm \mathrm{SD}(\%)$ for each element were: Fe (92 $\pm 3.421 \%), M n(95 \pm 0.897 \%), \mathrm{Zn}(102$ $\pm 1.083 \%), \quad C d(105 \pm 0.764 \%), K(99 \pm 0.543 \%), C a \quad(92$ $\pm 2.121 \%), \operatorname{Mg}(89 \pm 3.211 \%)$.

Metal concentration was obtained as the arithmetic average of three readings.

\section{Statistical analysis}

The results of the present study were processed by ANOVA one-way and the least significant difference test, in order to compare the mean values of the investigated parameters. The statistical processing and interpretation of the metal results of the trifactorial experience had as variation source hemp varieties, three different agrofonds, two seeding distances used and the three repetitions obtained after the parallel analysis of the samples. Computations Tukey post-hoc means comparisons and Levene's test for equal variance was also included. Statistically significant differences are marked (*) and indicate a p value $<0.05$. Statistically highly significant differences are marked (**) and indicate a p value $<0.01$. Statistically extremely significant differences are marked $(* * *)$ and indicate a $\mathrm{p}$ value $<0.001$. Statistical processing of data was performed using the Statistical Analysis System - SAS (Software Version 8.1. SAS Institute, Inc., Cary, NC).

\section{Competing interests}

The authors declare that they have no competing interests.

\section{Authors' contributions}

MM, GP, EA, IR contributed equally to the study design, collection of data, development of the soil and vegetables sampling, analyses, interpretation of results and preparation of the paper. All authors read and approved the final manuscript.

Received: 22 July 2012 Accepted: 12 October 2012

Published: 23 October 2012

\section{References}

1. Mölleken H, Theimer RR: Survey of minor fatty acids in Cannabis sativa L. fruits of various origins. Journal of the International Hemp Association 1997, 4(1):13-17.

2. Vogl C: Comparing Hemp Seed Yields (Cannabis sativa L.) of an On-Farm Scientific Field Experiment to an On-Farm Agronomic Evaluation Under Organic Growing Conditions in Lower Austria. Journal of Industrial Hemp 2004, 9(1):37-49.

3. Eriksson M: Hemp seed cake as a protein feed for growing cattle, MSc thesis, student report 128. Swedish University of Agricultural Sciences: Department of Animal Environment and health; 2007.

4. Deferne JL, Pate DW: Hemp seed oil: A source of valuable essential fatty acids. Journal of the International Hemp Association 1996, 3(1):4-7.

5. Mediavilla V, Jonquera M, Schmid-Slembrouck I, Soldati A: A decimal code for growth stages of hemp (Cannabis sativa L.). Journal of the International Hemp Association 1998, 5(2):68-74.

6. Dulf FV, Bele C, Spinean S, Chedea VS, Zegrean G, Socaciu C: Comparative studies on fatty acid fingerprint from total lipids and phytosterol esters of some edible plant oils. Buletin USAMV-CN 2006, 62:225-230.
7. Alexa E, Dragomirescu A, Pop G, Jianu C, Dragos D: The use of FT-IR spectroscopy in the identification of vegetable oils adulteration. Journal of Food Agriculture\& Environment 2009, 7(2):20-24.

8. lancu OG, Buzgar N: Atlasul geochimic al metalelor grele din solurile municipiului laşi şi împrejurimi. laşi: Universitatea Alexandru loan Cuza Press; 2008.

9. Callaway JC, Tennil T, Pate DW: Occurrence of "omega-3"stearidonic acid (cis-6,9,12,15-octadecatetraenoic acid) in hemp (Cannabis sativa L.) seed. Journal of the International Hemp Association 1997, 3(2):61-63.

10. Simopoulos AP: Importance of the ratio of omega-6/omega-3 essential fatty acids: evolutionary aspects. In Omega-6/Omega-3 Essential Fatty Acid Ratio: The Scientific Evidence, World Review of Nutrition and Dietetics, Volume 92: Karger; 2003:1-174

11. Pop G, Alexa E, Vlase L, Peev C, Militaru AV, Pop DA: Sitosterol content of some rapeseeds cultivars developed in Romania. Planta Med 2009, 75(9):1003.

12. Pop G, Dragomirescu A, Alexa E, Peev C, Militaru AV, Pop DA: Researches regarding in vivo skin imagistic dermatologic evaluation of evening primrose oil (0enothera biennis L.). Planta Med 2009, 75(9):1024.

13. Leizer C, Ribnicky D, Poulev A, Dushenkov S, Raskin I: The Composition of Hemp Seed Oil and Its Potential as an Important Source of Nutrition. Journal of Nutraceuticals, Functional \& Medical Foods 2000, 2(4):35-53.

14. Bona E, Marsano F, Maria Cavaletto D, Berta G: Proteomic characterization of copper stress response in Cannabis sativaL. Roots. Protomics 2007, 7(7):1121-1130.

15. Linger $\mathrm{P}$, Mussing J, Fisher H, Kobert J: Industrial hemp (Cannabis sativa L.) growing on heavy metal contaminated soil fibre quality and phytoremediation potential. Industrial Crop and production 2002, 16(1):33-42

16. Wong $\mathrm{MH}$ : Ecological restoration of mine degraded soils, with emphasis on metal contaminated soils. Chemosphere 2003, 50:775-800.

17. Ivanova R, Angelova V, Delibaltova V, Ivanov K, Shamov D: Accumulation of heavy metals in fibre crops flax, cotton and hemp. J. Environ. Protect. Ecol 2003, 4:31-38

18. Puschenreiter M, Horak O, FriesI W, Hartl W: Low-cost agricultural measures to reduce heavy metal transfer in to the food chain - a review. Plant Soil Environ 2005, 51(1):1-11.

19. Korkmaz K, Kara SM, Ozkutlu F, Gul V: Monitoring of heavy metals and selected micronutrients in hempseeds from North-western Turkey. African Journal of Agricultural Research 2010, 5(6):463-467.

20. Callaway JC: Hempseed as a nutritional resource. Euphytica 2004, 140:65-72.

21. Caraiman Cojocaru P, Macoveanu M: Decontamination of polluted soil with cadmium and zinc using greenhouse phytoremediation. Environ Eng Manag J 2011, 3:349-355.

22. Sandru ID, Paraschivoiu R, Gauca C: Cultura cânepii. Timişoara: Ed. Helicon; 1996.

23. Haraszty A: Study of the Effects of Potassium Magnesium and Manganese Fertilizers on Fiber Production of Hemp Cannabis-Sativa. Acta Biologica Debrecina 1979, :113-120.

24. Khan MA, Wajid A, Noor S, Khattak Khan F, Akhter S, Rahman I: Effect of soil contamination on some heavy metals content of Cannabis sativa L. J. Chem. Soc. Park 2008, 30(6):805-809.

25. Pendias AK, Pendias H: Trace Elements in soils and plants. New York: CRC Press; 1984.

26. Smith M: Manganes and Cobalt in heavy metals in soil. B.J: Alloway Blackie Press, Glasgow; 1990.

27. Knezevic M, Stankovic D, Krstic B, Sijacic Nikolic M, Vilotic D: Concentrations of heavy metals in soil and leaves of plant species Paulownia elongata $S$. Y.Hu and Paulownia fortunei Hemsl. Afr J Biotechnol 2009, 8(20):5422-5429.

28. FDA (Food and Drug Administration): Dietary Reference Intakes for Vitamin A, Vitamin K, Arsenic, Boron, Chromium, Copper, lodine, Iron, Manganese, Molybdenum, Nickel, Silicon, Vanadium, and Zinc, Report of the Panel on Micronutrients. Washington, DC: National Academy Press; 2001. Food and Drug Administration. Dietary supplements. Center for Food Safety and Applied Nutrition.

29. Kloke A, Sauerbeck DR, Vetter H: The contamination of soils and plants with heavy metals and the transport of heavy metals with terrestrial food chains. In Changing metale cycle and human health. Edited by Nriagu J. Berlin: Springer Verlag; 1984:113-141.

30. Adriano DC: Trace elements in the terrestrial environment. New York: Springer; 1986. 
31. Page AL: Cadmium absorption and growth of various plant species as influenced by solution cadmium concentration. J Environ Qual 1972, 1:271-288.

32. MWFEP, (Romanian Ministry of Water, Forest and Environmental Protection): Order756/1997 approving the Regulation on the assessment of environmental pollution values for traces of chemical elements in soil. Romania: The Official Monitor (MO) no 33bis; 1997 http://www.epcmediu.ro/system/files/ordin_nr. 756_din_3_noiembrie_1997.pdf.

33. Callaway JC, Pate DW: Hempseed oil. In Gourmet and Health- Promoting Specialty Oils. Edited by Moreau RA, Kamal-Eldin A. 2009:185-213.

34. Berbecea AA, Radulov I, Sala F, Crista F, Lato A: Interrelation between metal availability, soil pH and mineral fertilization. RJAS 2011, 43(3):19-23.

35. Tabără V: Influența fertilizării cu NPK asupra producției de samanta la canepa. Lucrari Stiintifice, Institutul Agronomic Timisoara, Agronomie 1984, 19:45-51.

36. Berbecea AA, Radulov I, Sala F, Crista F: Trace elements and metal bioavailablity in soils treated with industrial residues. RJAS 2010, 42(3):25-30.

37. SR EN ISO 659:2009: Oilseeds - Determination of oil content (Reference method) (ISO 659:2009). Romanian Standards Association (ASRO); 2009 http://magazin.asro.ro/.

38. AOAC 920.158: Hanus Method. In Official Methods of Analysis. 15th edition. Edited by Helrich K. Arlington, VA: AOAC International; 1990:776-782.

39. USEPA: United States Environmental Protection Agency: Method 3050B: Acid digestion of sediments, sludges, soils, \& oils, SW-846. Washington, DC: USEPA; 1996 [www.epa.gov/osw/hazard/testmethods/sw846/pdfs/3050b.pdf]

40. Banat Map. http://www.travelblog.org/Europe/Romania/Banat/map-banat. html.

41. Tabără V: Fitotehnie, Plante tehnice oleaginoase şi textile, Volume I. Timişoara: Brumar Press; 2005

42. Anwar F, Latif S, Ashraf M: Analytical Characterization of Hemp (Cannabis sativa) Seed Oil from Different Agro-ecological Zones of Pakistan. JAOCS 2006, 83(4):323-329.

doi:10.1186/1752-153X-6-122

Cite this article as: Mihoc et al: Nutritive quality of romanian hemp varieties (Cannabis sativa $L$.) with special focus on oil and metal contents of seeds. Chemistry Central Journal 2012 6:122.

\section{Publish with ChemistryCentral and every scientist can read your work free of charge \\ "Open access provides opportunities to our colleagues in other parts of the globe, by allowing anyone to view the content free of charge." \\ W. Jeffery Hurst, The Hershey Company. \\ - available free of charge to the entire scientific community \\ - peer reviewed and published immediately upon acceptance \\ - cited in PubMed and archived on PubMed Central \\ - yours - you keep the copyright \\ Submit your manuscript here: \\ http://www.chemistrycentral.com/manuscript/<smiles>c1ccccc1</smiles> Chemistry Central}

